\title{
日光国立公園尾瀬ヶ原における利用者の意識構造に ついて
}

\author{
A Study of the Consciousness Structure of Visitors to Oze in Nikko National Park \\ 山本 清龍* 麻生 恵 ${ }^{* *}$ 栗田 和弥** \\ Kiyotatsu YAMAMOTO Megumi ASO Kazuya KURITA
}

\begin{abstract}
When we think about carrying capacity of natural park, it is very important to have a clear grasp of visitors consciousness structure, such as satisfaction and awareness of congestion. This paper deals with Oze, Nikko National Park which is called as the birthplace of nature conservation of Japan and we have tried to get hold of visitors amenity and disamenity. From the analysis, we found that there are some elements and factors that influence for synthetic evaluation and there are some independent factors in the structure. As a result, we could suggest that it is needed more consideration about elements, factors and the relation among them to increase visitors amenity and to decrease their disamenity.
\end{abstract}

Keywords: Nikko National Park, Oze, amenity, disamenity, congestion, consciousness structure キーワード：日光国立公園, 尾瀬, アメニティ, ディスアメニティ, 混雑, 意識構造

\section{1. 背景と目的}

日光国立公園内に位置する尾瀬は，その極めて優れた景観や学 術上の貴重さだけでなく, 開発と自然保護の軋軪, 保護上利用の 両立といった，いくつもの困難な課題が大きな社会問題となった ことにより，わが国の自然保護のシンボルと言われ続けてきた。 歴史的な大きな問題として, 電源開発を巡る論争, 自動車道路建 設問題, 過剩利用問題等があり, 近年の問題としては, 踏みつけ による植生破壊や廃水処理問題, 移入種による生態系の覺乱, 過 剩利用の問題等がある ${ }^{1}$ 。一般的に自然公園の過剩利用という概 念は，利用者の増加による影響が自然の持つ許容量を超えて自然 環境に破壊が生じることを指すが, 本稿では利用者が集中する休 日において，木道や施設周辺が混雑を極め静かに自然を楽しむこ とが出来ない状況, 即ち利用者の利用環境を問題として捉える。

以上の視点に立ち, 本研究では日光国立公園尾瀬地域の利用環 境を取り上げ, 利用環境を顕わす一つの指標としてアメニティの 概念を導入し，混雑期における利用者の意識構造を把握すること を目的とした。具体的には利用者のアメニティをアメニティ要素 とディスアメニティ要素 ${ }^{2)}$ に整理し, 利用者の満足評価や混雑に 対する意識評価との相互関連について分析を行い，アメニティの 構造性について考察を行った。

既往研究のうち, 自然公園利用者の混雑感については, 青木に よる都市公園の同時在園者数と来園者の混雑感の関連を分析した あの ${ }^{3)}$ や, 愛甲, 浅川, 小林らによる大雪山国立公園の登山者, キャンプ場利用者を対象とした一連の研究4)等があり,それらの 多くが利用者数のコントロールに根拠を与えることを目的として いるが, 本研究はこうした議論の前提となる利用者の意識構造の 全体性に着目したあの上位置づけられる。また, アメニティにつ いては, 1976 年の OECD 環境委員会が我が国の環境政策に対す るアメニティの久如を指摘したことを契機に，ランドスケープ (造園) ${ }^{5)}$ や都市計画 ${ }^{6)}$ の分野において議論が行われてきたが, 評 価基準や評価手法といった技術理論の構築にはまだ研究の蓄積が 少ない。アメニティに関わる研究では, 解析手法として SD (Semantic Differential technique) 法が多く用いられ, その他とし て, 香川, 井川原 ${ }^{7}$ にる森林空間のアメニティの階層構造と因 子把握に括いて AHP の手法の提示が為されており, 本研究では
更に共分散構造分析を用いた解析手法を提示する。

\section{2. 研究方法}

\section{(1) 調查方法および調查対象地}

尾瀬利用者のアメニティを把握するために, 日光国立公園尾瀬 地区の中であ尾瀬ヶ原（図－1）の木道上に位置する牛首分岐 （写真－1）および竜宮の休想テラスにおいてアンケート調查を 行った。調查日は尾瀬の入山者数が一年で最む多いミズバショウ 期（平成 13 年 $6 / 9 \cdot 10$ ，土・日），ニッコウキスゲ期（同 $7 / 21$ ・ 22 , 土・日), 紅葉期 (同 $10 / 7 \cdot 8$, 日・祝) の 3 回とし, 本研究 に拈いては前 2 回をアメニティ要素とディスアメニティ要素を抽 出するための予備調查, 第 3 回をアメニティを総合的に把握する ための本調查として位置づけた。

\section{(2) アンケート調查の概要}

アンケート調查 (表一 1) は混雑する時期の利用者のアメ二ティ を把握するため, 利用者属性および利用特性の他に，予備調查で 抽出された各要素をそれぞれ項目として整理した 21 項目のアメ ニティ要素と 30 項目のディスアメニティ要素, 更に尾瀬来訪に 対する満足評価と混雑に対する意識評価を質問項目とした。アメ ニティ要素とディスアメニティ要素については, 被験者の負担を 軽減させるため，そう思う項目にはチェックを入れてあらう2 段 階の評価尺度とした。また, 満足評価は「満足した一満足しなかっ た」の 11 段階，混雑に対する意識評価は「気になった一気にな らなかった」の 11 段階の評価尺度を用いた。

利用者属性と利用特性を併せた利用者特性は表一-2のようにな り，女性が過半数であること, 50 代が半数近くを占めているこ 之，関東圈からの来訪者が多いことを示した。また，来訪回数は 初めての人が 3 割強, グループ人数では 3 人以上を構成する割合 が最皇高かった。さらに, 交通手段はマイカ一率が約 7 割を占め, 滞在日数は日州りの来訪者が約半数を占めた。全サンプル数は 2 47 , 調查 2 日間の尾瀬入山者数 12,963 人に対するサンプル率は $1.9 \%$ でった。

\section{3. 分析結果}

（1）アメニティの意識量分析

“東京大学大学院農学生命科学研究科 **東京農業大学大学院農学研究科 

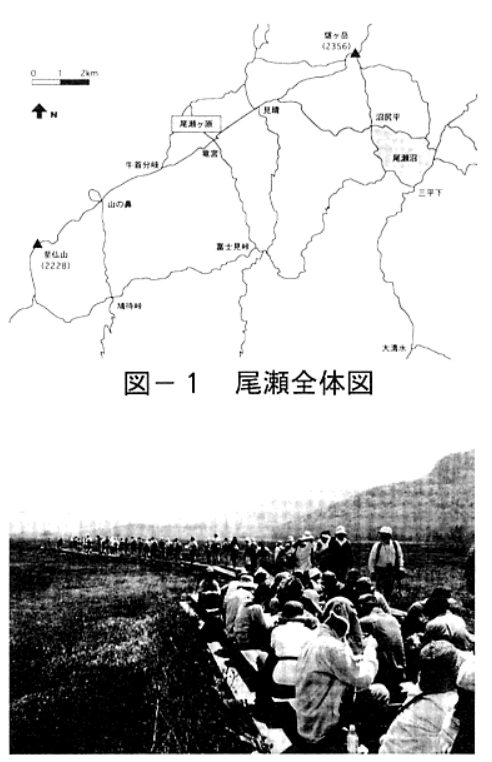

写真- 1 牛首分岐の休䕀テラスと木 道上を歩く人々（平成 14 年 6 月 8 日）
表ー 1 アンケート

調査の質問項目

\begin{tabular}{|l|}
\hline 1. 利用者属性 \\
(1)年齢 \\
(2)性別 \\
(3)住所 \\
2. 利用特性 \\
(1)来訪回数 \\
(2)グループ人数 \\
(3)交通手段 \\
(4)漫在日数 \\
3. アメニティ要素 \\
(21項目) \\
4. ティスアメニティ要素 \\
(30項目) \\
5. 満足評価 \\
(11段階評価) \\
6. 混雑に対する意識評価 \\
(11段階評価) \\
\end{tabular}

本研究ではまず, アメニティをアメニティ要素とディスアメニ ティ要素の 2 つに分類して, 量的な把握を行った。表一 3 を見る と, 上位に挙げられるアメニティ要素から尾瀬の優れた景観や自 然を評価する姿勢 $(\mathrm{A} 10,1)$ を見てとることが出来る。また，第 3 位には自然がまもられているその様子を評価する傾向（A12） が件数として把握された。さらに第 4 位, 第 5 位には利用者が他 の利用者を含めた利用マナーについて評価する姿勢（A17,3）が うかがえる。一方，ディスアメニティ要素は一人当たりに挙げら れる件数がアメニティ要素の 11.5 件と比較して，3.3 件と少なく, 分散する傾向も見られた。上位（D16,9）には利用者数に起因す ると考えられる項目が挙げられ，その他第 2 位（D22）に「植物 の名前が分からなかった」, 第 4 位（D20）に「思ったほど紅葉 がきれいでなかった」, 第5 位（D5）に「橋が狭くて危険だった」 が位置した。

（2）意識量と満足評価および混雑に対する意識評価の構造分析

次に, アメニティ要素とディスアメニティ要素が, 総合評価と 位置づけられる満足評価や混雑に対する意識評価に対してどの程 度寄与しているかを把握するため, 数量化 I 類による分析を行っ た。本分析では，満足評価を目的変数とし満足評価に寄与すると 考えられるアメ二ティ要素とディスアメニティ要素を説明变数と する分析，さらに混雑に対する意識評価を目的变数とし混雑に対 する意識評価に寄与すると考えられるディスアメニティ要素を説 明変数とする分析をそれぞれ行った。

図一 2,3 はそれぞれ, 満足評価に寄与する各要素のカテゴリー スコアと混雑に対する意識評価に寄与するディスアメニティ要素 のカテゴリースコアをグラフにしたあのである。分析の結果, 満 足評価に対してプラスに寄与するアメニティ要素として, 尾瀬の 自然を評価する項目 $(\mathrm{A} 2,7,10)$ や利用人数の少なさ（A5), 休 息出来たことを評価する項目（A21）が把握された。同様にディ スアメニティ要素の中から「テントを張れる場所の少なさ」（D 27)，「施設整備のいきすぎ」(D7),「紅葉がきれいでない」(D 20), 「落ち着かない」(D30),「トイレの污れ」(D28) が満足評 価にマイナスに寄与する項目として把握された。その他, 理論的 にはアメニティ要素は満足評伴にプラスに寄与し, ディスアメ二 ティ要素はマイナスに寄与すると考えられるが, 関連を殆ど見出 せないものや, 反対の符号を持つものがあることが明らかとなっ た。
表 -2 利用者特性

\begin{tabular}{|c|c|c|c|}
\hline \multicolumn{2}{|r|}{ 属性 } & 件数 & 割合 \\
\hline \multirow{2}{*}{$\begin{array}{l}\text { 性 } \\
\text { 别 }\end{array}$} & 男 & 113 & $46 \%$ \\
\hline & 女 & 134 & $54 \%$ \\
\hline \multirow{8}{*}{$\begin{array}{l}\text { 年 } \\
\text { 㱓 }\end{array}$} & 10 代 & 2 & $1 \%$ \\
\hline & 20 代 & 31 & $13 \%$ \\
\hline & 30代 & 26 & $11 \%$ \\
\hline & 40代 & 42 & $17 \%$ \\
\hline & 50 代 & 109 & $44 \%$ \\
\hline & 60 代 & 32 & $13 \%$ \\
\hline & 70代 & 4 & $2 \%$ \\
\hline & $\begin{array}{l}\text { 無回答 } \\
\end{array}$ & 1 & $0.4 \%$ \\
\hline \multirow{4}{*}{$\begin{array}{l}\text { 住 } \\
\text { 所 }\end{array}$} & 1 東京 & 54 & $22 \%$ \\
\hline & 2 埼五 & 48 & $19 \%$ \\
\hline & 3神奈川 & 27 & $11 \%$ \\
\hline & その他 & 118 & $48 \%$ \\
\hline
\end{tabular}

\begin{tabular}{|c|c|c|c|}
\hline \multirow{5}{*}{$\begin{array}{l}\text { 来 } \\
\text { 敫 } \\
\text { 回 } \\
\text { 数 }\end{array}$} & 初めて & 82 & $33 \%$ \\
\hline & 2-3回目 & 69 & $28 \%$ \\
\hline & 4-9回目 & 58 & $23 \%$ \\
\hline & 10-19回目 & 22 & $9 \%$ \\
\hline & 20回以上 & 16 & $6 \%$ \\
\hline \multirow{3}{*}{ 人 } & 1人 & 11 & $4 \%$ \\
\hline & $2 人$ & 117 & $47 \%$ \\
\hline & 3 人以上 & 119 & $48 \%$ \\
\hline \multirow{4}{*}{$\begin{array}{l}\text { 交 } \\
\text { 通 } \\
\text { 手 } \\
\text { 段 }\end{array}$} & マイカー & 169 & $68 \%$ \\
\hline & 公共交通 & 21 & $9 \%$ \\
\hline & シアーパス & 54 & $22 \%$ \\
\hline & その他 & 3 & $1 \%$ \\
\hline \multirow{3}{*}{ 浿 在 数 } & 1日 (日鮆り) & 122 & $49 \%$ \\
\hline & 2日（1泊） & 106 & $43 \%$ \\
\hline & 3日（2泊以上） & 19 & $8 \%$ \\
\hline & 合乾 & 247 & $100 \%$ \\
\hline
\end{tabular}

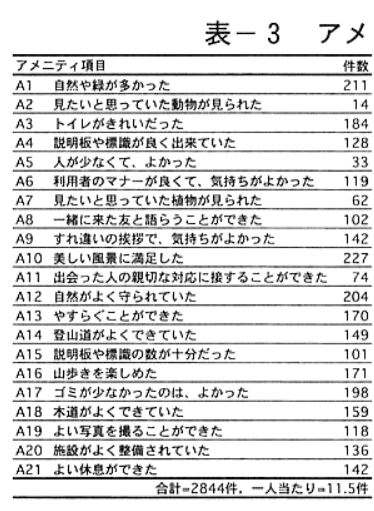

A=Amenity, D=Disamenity

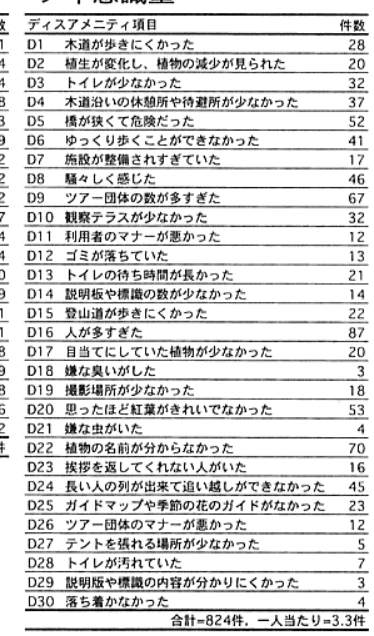

また，混雑に対する意識評価にプラスに寄与するディスアメニ ティ要素の中には, 生理的な我慢を要したことに対してその要因 を混雑に対する意識評価に反映させているもの（D13）が含まれ る他, 自然を楽しむ上で必要とされる情報が得られないこと （D29）が混雑に対する意識評価を増加させていることが分かる。

（3）アメニティ要素とディスアメニティ要素の因子分析

本分析では, アメニティ意識量と尾瀬利用に関わる総合評価の 「満足評価」と「混雑に対する意識評価」の構造を把握するため の構造モデルの構築を視野に入れて因子分析を行った。

表 -4 は Kaiser 基準により, 回転前の固有値が 1 以上の因子 を抽出し，更にバリマックス回転後に得ら扎アメニティ要素の 因子負荷量である。第 1 因子（回転前の寄与率：23.0\%）は「休 息・語らいに対する満足」, 第 2 因子（同：8.2\%）は「施設に対 する満足」，第 3 因子（同：5.9\%）は「利用者マナーに対する満 足」, 第 4 因子（同：5.7\%）は「動植物の観察に対する満足」, 第 5 因子（同：5.1\%）は「山歩きに対する満足」を表す因子で あると解釈された。また, 回転前の因子負荷量から「休息・語ら いに対する満足」がアメニティの評価軸として最も重要視される 傾向が明らかとなった。

また, 表一 5 はディスアメニティ要素のバリマックス回転後の 因子負荷量である。Kaiser 基準では, 回転前の固有値 1 以上の 因子が 13 残ることから, Cattell 基準に準じた。第 1 因子（回転 前の寄与率：9.2\%）は「利用環境に対する不満」, 第 2 因子（同： 8.3\%) は「施設整備状況に対する不満」, 第 3 因子（同：5.9\%) は「利用者マナーに対する不満」と解釉された。これにより, 回 転前の因子負荷量から「利用環境に対する不満」がディスアメ二 ティの評価軸として重要視される傾向が明らかとなった。

冒頭で述べたように本研究では, 尾瀬利用者の利用環境を問題 

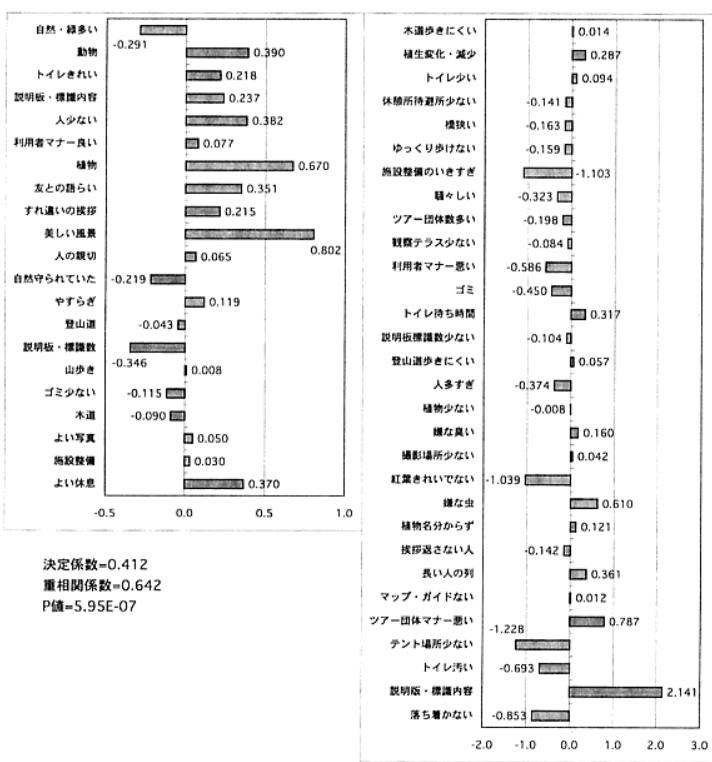

図－2 満足評価に寄与する各要素のカテゴリースコア $(n=247)$

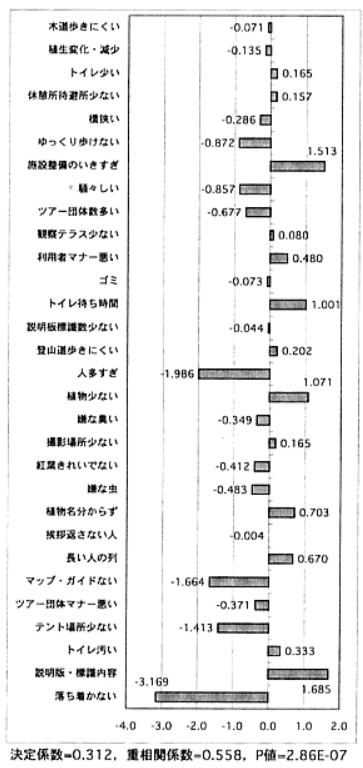

図一－：混雑に対する意識評 価へ寄与する各要素のカテゴ リースコア $(n=247)$

\begin{tabular}{|c|c|c|c|c|c|c|}
\hline \multirow{2}{*}{\multicolumn{2}{|c|}{ アメニティ項目 }} & \multicolumn{5}{|c|}{ 因子 } \\
\hline & & 1 & 2 & 3 & 4 & 5 \\
\hline A13 & やすらを & 0.691 & 0.025 & 0.115 & -0.035 & 0.236 \\
\hline$A B$ & 友との語らい & 0.613 & 0.152 & 0.008 & 0.254 & -0.030 \\
\hline A21 & よい休息 & 0.595 & 0.319 & 0.215 & -0.052 & 0.091 \\
\hline A1 & 自然・错多い & 0.567 & -0.026 & 0.078 & -0.026 & 0.149 \\
\hline A4 & 镜期板 & 0.100 & 0.690 & 0.089 & 0.123 & 0.243 \\
\hline A15 & 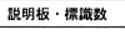 & 0.014 & 0.669 & 0.223 & 0.166 & 0.161 \\
\hline A3 & トイレきれい & 0.209 & 0.615 & -0.172 & -0.064 & -0.115 \\
\hline A20 & 施政整佩 & 0.095 & 0.591 & 0.099 & 0.192 & 0.213 \\
\hline A17 & コミ少ない & 0.016 & 0.486 & 0.444 & -0.210 & -0.002 \\
\hline A6 & 利用者マナー良い & 0.123 & 0.177 & 0.652 & 0.090 & 0.131 \\
\hline A5 & 人少ない & 0.056 & -0.033 & 0.623 & -0.043 & 0.070 \\
\hline A9 & すれ连いの挨猡 & 0.460 & 0.093 & 0.468 & 0.221 & 0.045 \\
\hline A19 & よい写真 & 0.313 & -0.042 & 0.458 & 0.411 & 0.148 \\
\hline Al1 & 人の视切 & 0.276 & 0.183 & 0.447 & 0.232 & 0.144 \\
\hline A12 & 自然宁られていた & 0.050 & 0.286 & 0.444 & -0.164 & 0.168 \\
\hline $\mathrm{A} 2_{2}$ & 動物 & 0.020 & 0.088 & 0.004 & 0.728 & -0.071 \\
\hline A7 & 植物 & 0.052 & 0.194 & 0.080 & 0.560 & 0.239 \\
\hline A14 & 僜山道 & 0.114 & 0.266 & 0.164 & -0.063 & 0.687 \\
\hline A18 & 木道 & -0.023 & 0.439 & 0.027 & 0.005 & 0.619 \\
\hline $\mathrm{A} 10$ & 美しい風暴 & 0.165 & -0.081 & 0.139 & 0.138 & 0.588 \\
\hline A16 & 山紫老 & 0.429 & -0.001 & 0.014 & 0.092 & 0.581 \\
\hline & 距明湾 & 2.226 & 2.488 & 2.052 & 1.381 & 1.926 \\
\hline & 需与事 & 0.106 & 0.118 & 0.098 & 0.066 & 0.092 \\
\hline
\end{tabular}

表 -5

ディスアメニティ要素の因子負荷量

として捉える視点を持つため, 第 1 因子に対する因子負荷量が大

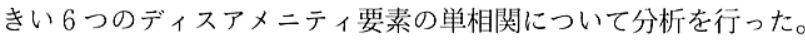
その結果, 「人が多すぎた」は「長い人の列が出来て追い越しが 出来なかった」（相関係数：0.311），「騒々しく感じた」（同： 0.431),「ッアー団体の数が多すぎた」（相関係数：0.427）とな り，入山者数の制限を設けないという条件下において利用環境を 改善する方法として, 木道の複線化, 団体規模の縮小化 (分割), 木道之休数場所の距離の拡大等が考えられる。

\section{（4）意識構造モデル}

数量化 I 類および因子分析の結果を踏まえて，意識構造をより 包括的，定量的に把握するため共分散構造分析を行った。アメ二 ティ要素とディスアメニティ要素の意識量をそれぞれ観測変数と し，因子分析においてアメ二ティ因子として導かれた 5 つの因子 と，ディスアメニティ因子として導かれた 3 つの因子をモデル構 築のための潜在变数とした。作成したモデルは「満足の意識構造 モデル」拈よび「混雑に対する意識構造モデル」の 2 つであり, これらのモデルは様々な仮説を立てて推計し，最屯適合度が高かっ たモデルである。またその際, 統計的に有意とならなかったアメ ニティおよびディスアメニティの各要素は削除した。尚, 利用者 特性は寄与率が高くならないことを考慮し，モデルに組み込んで いない。

図ー 4 は満足の意識構造モデルであり，因子間のパス作成を試 みた結果, 適合度指標の值が下がることから, 新たなパスの設定 を行わず，因子間の共分散を設定して作成したものである。適合 度指標である GFI，AGFI の值はそれぞれ $0.836,0.813$ となり 比較的良い值となっている。各因子から満足評価への係数につい ては, 統計的に有意とはならなかったが, 因子と各要素は全て 5 \%で有意であった。図を見ると，満足評価にプラスに影響を与え るものとして「動植物の観察に対する満足」の因子が寄与し, 中 でも「見たいと思っていた植物が見られた」(A7) ことが大きく 満足評価を増加させることが明らかとなった。また，「施設に対 する満足」を表す因子は要素として挙げられながらも，総合的な 満足に対してマイナスの係数となり，その他利用者のマナーや山 歩きの満足を含め，これらの因子と満足評価の間に関係を見出す ことは出来ない。一方, ディスアメニティ因子は全て満足評価に

\begin{tabular}{|c|c|c|c|}
\hline \multirow{2}{*}{ ディスアメニティ项目 } & \multicolumn{3}{|c|}{ 因子 } \\
\hline & 1 & 2 & 3 \\
\hline D16 人多すき & 0.709 & -0.063 & 0.146 \\
\hline D24 長い人の列 & 0.682 & 0.195 & -0.109 \\
\hline D8 殿々しい & 0.653 & -0.078 & 0.125 \\
\hline D9 ッアー团体数多い & 0.638 & -0.036 & 0.238 \\
\hline D13 トイレ待ち時間 & 0.157 & 0.069 & -0.095 \\
\hline D28 トイレ污い & 0.128 & 0.024 & 0.067 \\
\hline D4 休盼所待起所少ない & -0.121 & 0.638 & 0.085 \\
\hline D10 显テラス少ない & 0.137 & 0.581 & -0.125 \\
\hline D25 マッフ・カカイトない & -0.036 & 0.526 & -0.014 \\
\hline D6 由っくり扮けない & 0.300 & 0.468 & 0.088 \\
\hline $\begin{array}{ll}\text { D5 情狭い } \\
\end{array}$ & 0.111 & 0.453 & -0.106 \\
\hline 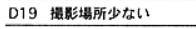 & -0.025 & 0.459 & -0.054 \\
\hline 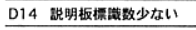 & -0.022 & 0.426 & 0.074 \\
\hline D15 登山道步きにくい & -0.055 & 0.409 & 0.064 \\
\hline 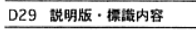 & -0.143 & 0.366 & 0.256 \\
\hline D3 トイレ少い & 0.097 & 0.360 & -0.022 \\
\hline D22 植物名分からず & -0.243 & 0.311 & 0.023 \\
\hline D30 落与著かない & 0.223 & 0.225 & -0.151 \\
\hline D1 木道步きにくい & -0.092 & 0.180 & 0.077 \\
\hline D18 峻な & 0.103 & 0.127 & 0.071 \\
\hline D26 ッアー团俈マナー恶い & 0.180 & -0.142 & 0.657 \\
\hline D11 利用者マナー㤠い & 0.235 & 0.029 & 0.653 \\
\hline D12 Jミ & -0.019 & 0.095 & 0.617 \\
\hline 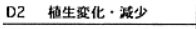 & 0.041 & 0.080 & 0.478 \\
\hline 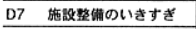 & -0.027 & 0.023 & 0.457 \\
\hline D23 挨拉返さない人 & 0.117 & 0.097 & 0.294 \\
\hline D20 k㹎きれいてない & -0.093 & 0.019 & 0.239 \\
\hline D27 テント場所少ない & 0.138 & -0.048 & 0.18 \\
\hline D21样な中 & 0.072 & -0.100 & -0.135 \\
\hline D17 值物少ない & -0.069 & 0.062 & 0.090 \\
\hline 锐明㴒 & 2.284 & 2.583 & 2.153 \\
\hline 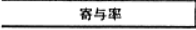 & 0.076 & 0.086 & 0.072 \\
\hline
\end{tabular}

マイナスに寄与しており， 一般的に予想される通り の結果が得られた。中で 屯「利用環境に対する不 満」因子は満足評価を大 きく下げる傾向にあり, この因子に関わりのある 要素のうち特に「人が多 すぎた」（D16）へのパ 又係数が最も高い。

図- 5 は同様に混雑に 対する意識構造モデルで ある。適合度指標は $\mathrm{GF}$ I0.897, AGFI0.874 とな り，良好な結果が得られ た。*を付した一部の係 数を除き, 多くの係数が 統計的に有意であった。 この図を見ると混雑に対 する意識評価に大きく影 響を与える因子として 「利用環境に対する不満」 を表す因子があり，特に「人が多すぎた」(D16) ことがその原 因となっている。また，「利用環境に対する不満」因子は「利用 者マナーに対する不満」因子にも影響を与え，ディスアメニティ 要素である「利用者のマナー」の評価へと敖がりを見せる。一方, 「施設整備状況に対する不満」因子は「木道沿いの休㕰場所や待 避所が少なかった」（D4）を中心に構成するむのの, 混雑に対す る意識構造モデルの中でやや独立した評価因子として位置づけら れる。

更に本研究で利用環境を重視する視点から，特に利用環境が悪 化したと考えられる 10 月 7 日について，同じモデルにおける検 討を行った。尚, 10 月 7 日と 8 日の尾瀬入山者数はそれぞれ 8,954 人と 4,009 人である。図- 6 を見ると, 尾瀬入山者数の増 加から最屯影響を受けると考えられる「利用環境に対する不満」 


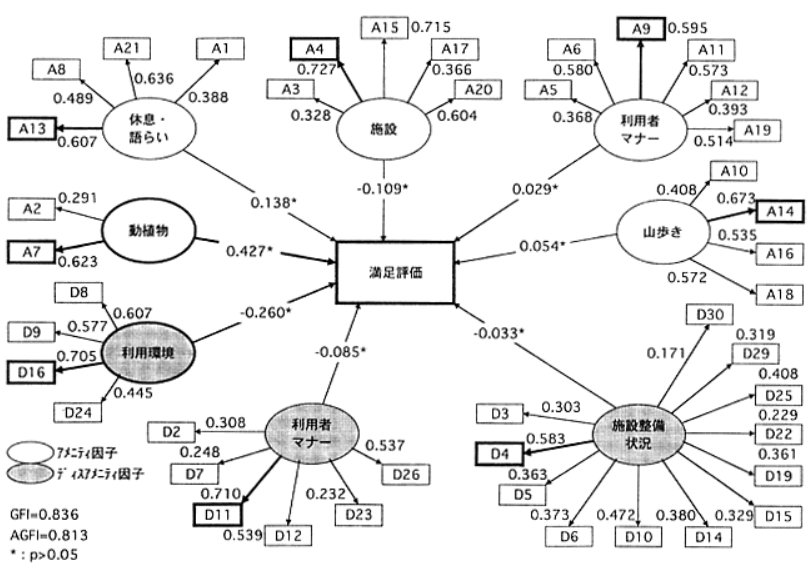

図ー 4 満足の意識構造モデル

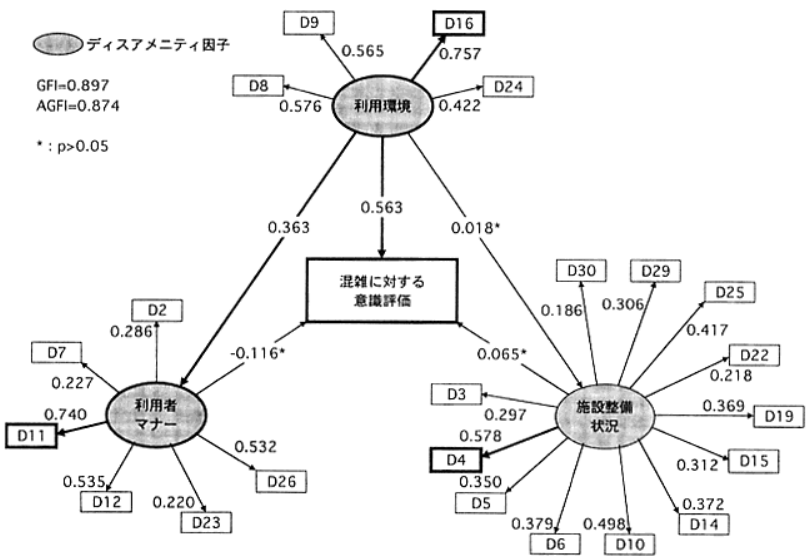

図ー 5 混雑に対する意識構造モデル

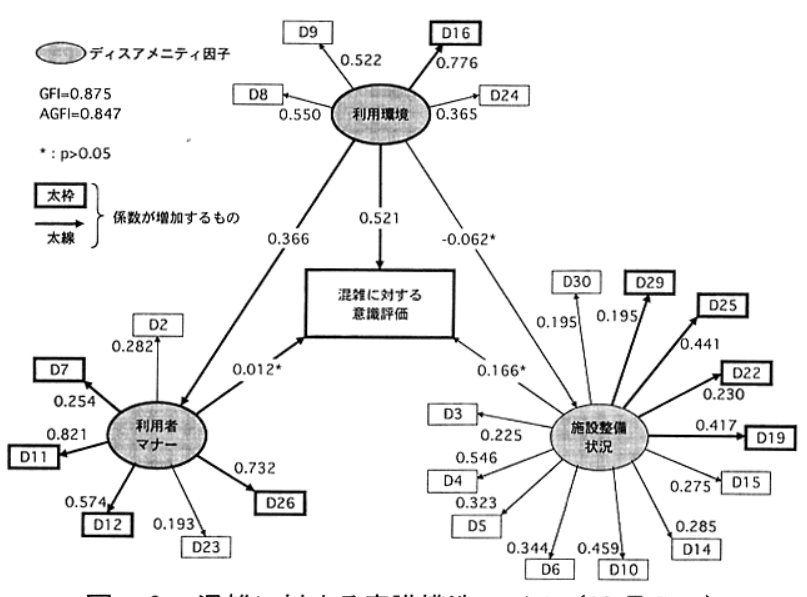

図－6＼cjkstart混雑に対する意識構造モデル（10月７日）

因子から「人が多すぎた」（D16）へのパス係数が増加している。 これを起点として解釈すると,「利用環境に対する不満」の増加 は混雑に対する意識を増加させ，「利用者マナーに対する不満」 屯増加するといえる。「施設整備状況に対する不満」はやはり独
立的であるが，標識や案内板（D29），ガイドマップ（D25）等 に対するマイナスの評価が増え, 情報を求める声が増大すると考 えられる。

\section{4. 考察}

本研究では日光国立公園尾瀬地域の利用環境を取り上げ，利用 環境を顕わす一つの指標としてアメニティの概念を導入し, 混雑 期における利用者の意識構造について検討を行った。アメニティ の意識量分析結果から, 件数として把握されるアメニティ要素と ディスアメニティ要素を明らかにし，意識量と満足評価および混 雑に対する意識評価の構造分析により, 意識量分析では把握され なかったものの中で, 総合的な評価へ強く寄与するものが存在す ることを把握した。また, アメニティ要素とディスアメニティ要 素の因子分析結果と意識構造モデルの検討結果により, 要素に潜 在する因子を明らかにし，因子の中でも独立的に存在する因子の 存在を明らかにした。アメニティの意識量だけでなく, 要素や因 子の寄与の大きさを考慮することにより, 尾瀬利用者のアメニティ を増加させ，ディスアメニティを減少させていく具体策について 検討することが可能となろう。また，混雑に対する意識構造モデ ルを用いて，10月 7 日の利用者の意識構造について明らかにし たが, 特に混雑した状況下において, その影響を受けない要素お よび因子の存在を確認した。国立公園尾瀬の利用適正化あるいは 効果的な利用の促進を図る場合に, こうした意識構造に内在する 要素, 因子の独立性, 構造性を考虑する必要があると言える。

最後に, 本研究は環境省が財団法人尾瀬保護財団に委託して実 施している国立公園利用適正化推進事業の一環として実施したも のであり, 関係者の皆様からは多大なる御協力を頂きました。ま た, 田園都市研究所一場博幸氏, 田村環境計画田村裕希氏, 千葉 大学古谷助教授には貴重な助言を頂きました。更に調查実施にあ たり, 下鴆聖氏, 望月寛氏を中心とする東京農業大学の学生の皆 様には大変お世話になりました。ここに感謝の意を表します。

\section{引用文献・参考文献}

1) 中島慶二（1998）尾瀬問題之国立公園管理：国立公園 562, 8-11

2) 本研究ではアメニティを, 利用者が尾瀬来訪時に満足として 挙げるアメニティ要素と不満として挙げるディスアメニティ 要素の 2 つに分類した。

3 ）青木陽二（1986）同時在園者数による混雑感の分析：造園雑 誌 50(2), 108-111

4 ）愛甲哲也・鄭佳昇・浅川昭一郎（2002）：自然公園における 写真を用いた混雑感と許容限界の把握について：ランドスケー プ研究 65(5), 669-672

5 ）油井正昭・熊谷洋一（1986-88）：造園学会全国大会分科会報 告: 造園雑誌 50(1)，21-27，51(1)，41-49，52(1)，35-44

6 ）西村幸夫 (1987) : 都市アメニティ論の現在: 都市計画 147 , $79-81$

7 ）井川原弘一・香川隆英（2000）：日本の代表的森林夕イプに おけるアメニティの比較考察：ランドスケープ研究 63(5), 583-586 